\title{
Performance and cost-benefit analysis of Isa Brown layers on different management systems
}

\author{
Daniel Adeolu Okedere ${ }^{1 *}$ (D, Peace Queen Ademola ${ }^{2}$ and Priscilla Mofifoluwa Asiwaju ${ }^{3}$
}

\begin{abstract}
Background: Few literatures exist on the performance and cost implication of birds reared on different management system. The cost benefit analysis of rearing Isa Brown layers on three different management systems was evaluated in a 9 (9)-week feeding trial. One hundred and forty-four (144) points of lay (19 weeks old) Isa-Brown chickens were procured from a reputable farm in Osun state. The birds were placed on three (3) treatments (battery cage, deep litter, and free range) of three (3) replicates and sixteen (16) birds per replicate in a completely randomized design. Birds reared on conventional cages were arranged into three birds per cage unit. Birds on deep litter were kept on wood shavings, in which perches, laying nests, feeders, and drinkers were provided. Hens on free range management system were kept in a large area of land camped using planks and hexagonal wire mesh which was partitioned into various replicates. Sheds were provided for the birds to protect them from harsh weather conditions, and perches, laying nests, feeders, and drinkers were also provided. The birds on all the treatments (battery cage, deep litter and free range) were given the same diet, and the study period lasted for sixty-five days. The weight gain per bird, percentage weight gain, hen day production (HDP), egg mass index, and feed conversion ratio were determined. At the end of the experiment, these records were used to evaluate economic indices.
\end{abstract}

Results: The result showed that only the feed intake and total feed intake were significantly $(p<0.05)$ influenced by management systems in all the parameters measured for performance. The daily feed intake, total feed intake total cost of feed consumed, quantity of egg produced per bird, revenue generated from eggs, production cost, net benefit, cost-benefit ratio, and percentage cost of production were significantly $(p<0.05)$ influenced by management systems. Birds kept on deep litter system recorded the highest (48.87) number of eggs produced. The cost of construction was recorded to be highest in battery cage system while construction of free range facilities was at the minimum. Revenue generated from egg sold was highest (1384.56) in deep litter system while free range recorded the least significant $(p<0.05)$ ( 1301.44$)$ value. Total cost of producing table eggs was significantly $(p<0.05)$ highest ( $\$ 2251.54)$ in battery cage, while free range had the least ( 12074.88 ) cost of production. Free range birds recorded the highest ( 1326.56$)$ net benefit, while the least (1195.24) net benefit was obtained in battery cage.

Conclusion: It was therefore concluded that free range management system resulted into better profit margin and could however be adopted by small scale farmers in rural areas willing to practice backyard poultry farming.

Keywords: Hen day production, Total cost of production, Cost-benefit ratio, Management systems and free range

\footnotetext{
* Correspondence: daniel.ayo84@yahoo.com

1 Department of Animal Production and Health, Federal University of

Technology, Akure, Nigeria

Full list of author information is available at the end of the article
}

\section{Springer Open}

(c) The Author(s). 2020 Open Access This article is licensed under a Creative Commons Attribution 4.0 International License, which permits use, sharing, adaptation, distribution and reproduction in any medium or format, as long as you give appropriate credit to the original author(s) and the source, provide a link to the Creative Commons licence, and indicate if changes were made. The images or other third party material in this article are included in the article's Creative Commons licence, unless indicated otherwise in a credit line to the material. If material is not included in the article's Creative Commons licence and your intended use is not permitted by statutory regulation or exceeds the permitted use, you will need to obtain permission directly from the copyright holder. To view a copy of this licence, visit http://creativecommons.org/licenses/by/4.0/. 


\section{Introduction}

Poultry industry is highly essential to Nigerian economy because it provides a good source of animal protein in meat and eggs (Nmadu et al. 2014). Poultry sector in Nigeria accounts for about $58.2 \%$ of overall livestock production (Amos 2006), as it offers the nippiest profit to investment expenditures in livestock production enterprise by its benefit of short generation interval, high feed conversion ratio together with being one of the inexpensive, easiest, and best sources of animal protein in the country (Ojo 2002). Poultry production is the most resourceful and profitable way of increasing the accessibility to high quality protein food, as eggs are recognized to provide the virtually a perfectly balanced food containing all the essential amino acids, minerals, and vitamins (Branckeart et al. 2000). In the same vein, Ayinde et al. (2012) reported that poultry industry is one of the major sources of animal proteins in Nigeria.

Globally, battery cages are the major system of housing laying hens (Horne and Achterbosch 2008; Leenstra et al. 2016 and Meseret 2016). This was because battery cages help to reduce sanitary problems in poultry production, and it helps to enhance labor effectiveness and space management. Also, it enhances a reduction in aggression and cannibalism among hens (Meseret 2016). But as good as battery cages seems to be, they constitute welfare problem to laying birds because they are barren, they restrict movement, prevent many natural behaviors, and increase rates of osteoporosis in hens (Meseret 2016). Due to the welfare problems constituted by battery cages, the European Union Council Directive 1999/74/EC (European Union Council Directive, 2012) banned the use of conventional battery cages in the European Union. Similarly, RSPCA considered the use of enriched cages as unacceptable and inhumane to the welfare of the poultry birds; therefore, they suggest that alternative methods such as barn, deep litter, and free range management systems should be imbibed (RSPCA 2005). Writerstake (2019) described deep litter system as the most popular intensive system of rearing poultry in East Africa. In this system of poultry production, birds are kept on the litter throughout their lifecycle. The structures of the deep litter system must include a large, well-ventilated house without draught, feeders and drinkers should be provided for the birds to eat and drink from comfortably, and perches and laying nests should also be provided for laying birds (Writerstake 2019). Recently, due to welfare issues associated with intensive poultry production through the use of battery cages, the interest in free-range poultry farming has been revived in the developed countries (Miao et al. 2005). Brambell (1965) reported that, for the best production performance in poultry, birds should be free from hunger, thirst, discomfort, pain, injury, disease, fear, and distress and be able to express normal behaviors. Free range method can be described as the system of poultry rearing using moveable housing with access to pasture (Poole 2008). In free-range systems, movable houses or cages are used and are relocated frequently so that chickens may have access to forages, seeds, and insects outside of the house during daytime hours and in the evening, the chickens come back to the shed prepared with the cage, which would then be relocated to a new spot for new foraging the following day (Damerow 2002).

As important as poultry is to Nigerian economy, poultry industry is faced with certain constraints which in turn caused many of the farmers to be forced out of the enterprise. Such constraints facing poultry enterprise include high cost of feed (Afolami et al. 2013), disease management, poor or erratic power supply, poor management practices, lack of storage or processing facilities, lack of technological know-how, and many more. Ayinde et al. (2012) stated that the deterioration of commercial poultry production has also been ascribed to the unavailability of day-old chicks, poor quality feeds, and occasionally insufficiency of the feed ingredients (especially grains), and poor veterinary services, unavailability of drugs and vaccines, and lack of capital for enlargement are the major problems affecting poultry production in Nigeria of which its primary production erupts from the rural environment. Alexander (2004) noted that in many developing countries including Nigeria, chickens are the livestock most commonly owned by rural families. Due to these constraints, the prices of meat and eggs are on the high side, making it unaffordable for many average Nigerians especially people in the rural area because of the reduced production and purchasing power. The high cost of animal protein has therefore led to the problem of protein-calorie malnutrition in many of the children from rural areas. Furthermore, Omololu (1999) revealed that the effects of low protein intake in children result in kwashiorkor, a form of protein-calorie malnutrition. It was discovered that children who have suffered from malnutrition may not attain the full expression of their genetic potential. The long-term effects of malnutrition are therefore a severe threat to human race (Burton and Cooper 2007; Osei 2008).

This study, which was designed for backyard poultry farmers, is therefore aimed at evaluating performance and cost benefit of keeping layers on different management systems (battery cage, deep litter, and free range) by comparing the performance and profitability of free range birds with the conventional methods.

\section{Materials and methods \\ Study location}

The field work of this study was carried out in Daeliza Farms and laboratory of Daeliza Foods and Agricultural Products located at Imuleke, Odo-Otin local government of Osun State. Odo Otin is a local government area in Osun State, Nigeria, and its headquarters are in the town 
of Okuku. It has an area of $294 \mathrm{~km}^{2}$ and a population of 134,110 as of the 2006 Nigerian census. The town is located within Latitude $8^{\circ} 01^{\prime \prime} \mathrm{N}$ and Longitude $4^{\circ} 42^{\prime \prime} \mathrm{E}$. The temperature typically varies from 64 to $92^{\circ} \mathrm{F}$. The mean annual rainfall is $1800 \mathrm{~mm}$, and the rain period is bimodal with a short break in August (Weather Spark 2017)

\section{Experimental birds arrangement and feeding}

One hundred and forty-four (144) points of lay (19 weeks old) Isa-Brown chicken were procured from a reputable farm in Osun state. The birds were placed on three (3) treatments of three (3) replicates and sixteen (16) birds per replicate in a completely randomized design. Birds reared on conventional cages were arranged into three birds per cage unit. Birds on deep litter were kept on wood shavings, in which perches, laying nests, feeders, and drinkers were provided. Hens on free range management system were kept in a large area of land camped using plank wood and hexagonal wire mesh which was partitioned into various replicates. Sheds were provided for the birds to protect them from harsh weather conditions, and perches, laying nests, feeders, and drinkers were also provided. The birds on all the treatments (battery cage, deep litter, and free range) were given the same diet (as shown in Table 1), and the study period lasted for sixty-five days.

Table 1 composition of the experimental diet

\begin{tabular}{ll}
\hline Ingredients & Quantity \\
\hline Maize & 64.15 \\
Wheat offal & 5.30 \\
Soybean meal & 18.00 \\
Limestone & 8.50 \\
Di calcium phosphate & 1.32 \\
Vegetable oil & 1.70 \\
Vitamin and mineral premix & 0.50 \\
Methionine & 0.08 \\
Lysine & 0.05 \\
Salt & 0.40 \\
Total & $\mathbf{1 0 0}$ \\
Calculated analysis & \\
Metabolizable energy & 2842.00 \\
Crude protein (\%) & 15.43 \\
Calcium (\%) & 3.63 \\
Crude fiber (\%) & 5.25 \\
Available phosphorus & 0.39 \\
Lysine & 0.53 \\
Methionine & 0.31 \\
Ether extract & 2.38 \\
\hline
\end{tabular}

\section{Data collection}

The weight of the birds was taken at the beginning of the experiment and at the end of each phase of the experimental period (3rd, 6th, and 9th weeks). The weight gain per bird was calculated by subtracting the initial weight of the bird from the final weight at the end of the experimental period. Percentage weight gain was also calculated by dividing the weight gain by the initial weight multiplied by 100 . A weighed quantity of feed was given to the birds every morning, and the quantity left over was collected and weighed to account for daily feed intake. At the end of each day, the hen day production (HDP) for each of the treatments was calculated by dividing the total number of eggs produced per day by the number of birds alive for that day, multiplied by 100 . Feed conversion ratio was calculated by dividing the daily feed intake by the egg mass and multiplied by 100 . Egg mass index was calculated by multiplying the hen day production with the egg weight. At the end of the experiment, these records were used to evaluate economic indices such as cost $/ \mathrm{kg}$ feed, cost of total feed consumed per bird, revenue from sales, net benefit, cost benefit rati,o and cost of feed per bird in relation to total variable costs. Cost of total feed consumed was calculated by multiplying total feed consumed in each treatment with the cost $/ \mathrm{kg}$ feed. The net benefit or profit index was obtained as revenue less the production cost. Cost-benefit ratio was obtained by dividing the net benefit by the revenue (Belewu et al. 2018).

\section{Statistical analysis}

All data collected were subjected to analysis of variance (ANOVA) using SPSS (2006) version 17, and the means were separated using Duncan's multiple range test (Duncan 1955) of the same package.

\section{Results \\ Performance of Isa Brown layers reared on three different management systems}

Table 2 showed the general performance of Isa Brown layers reared on three different management systems. In all the parameters measured, only the feed intake and total feed intake were significantly $(p<0.05)$ influenced by management systems. Highest $(p>0.05)$ values $(0.16$ and 9.41) of weight gain and percentage weight gain was recorded in free range birds while birds on battery cage and deep litter had values for weight gain that are statistically $(p>0.05)$ similar. However, least (5.78) percentage weight gain was recorded in battery cage birds. Egg weight reduced across the management systems with battery cage having the highest (59.5) egg weight while free range birds had the least value (55.78). Average egg produced per bird, hen day production, and egg mass index also reduced across the treatment with deep litter 
Table 2 Performance of Isa Brown layers reared on three different management systems

\begin{tabular}{|c|c|c|c|c|}
\hline Parameters & Battery cage & Deep litter & Free range & $p$ value \\
\hline Initial weight (kg) & $1.73 \pm 0.02$ & $1.71 \pm 0.03$ & $1.70 \pm 0.01$ & 0.73 \\
\hline Final weight (kg) & $1.63 \pm 0.06$ & $1.61 \pm 0.02$ & $1.54 \pm 0.02$ & 0.185 \\
\hline Weight gain (kg) & $0.10 \pm 0.07$ & $0.10 \pm 0.05$ & $0.16 \pm 0.02$ & 0.518 \\
\hline \%Weight gain & $5.78 \pm 3.77$ & $5.84 \pm 2.74$ & $9.41 \pm 1.05$ & 0.428 \\
\hline Egg weight (g) & $59.50 \pm 2.5$ & $58.15 \pm 2.16$ & $55.78 \pm 1.01$ & 0.432 \\
\hline Average egg/day & $22.14 \pm 0.71$ & $22.95 \pm 0.78$ & $21.52 \pm 1.39$ & 0.69 \\
\hline \%Hen day production & $73.79 \pm 2.37$ & $76.51 \pm 2.60$ & $71.74 \pm 4.64$ & 0.691 \\
\hline Egg mass index & $43.91 \pm 3.07$ & $44.45 \pm 0.82$ & $40.01 \pm 2.27$ & 0.285 \\
\hline Daily feed intake (g) & $114.83 \pm 0.17^{a}$ & $114.00 \pm 0.52^{\mathrm{a}}$ & $109.67 \pm 0.42^{b}$ & $<0.001$ \\
\hline Total feed intake (g) & $7463.95 \pm 1.2^{a}$ & $7410.00 \pm 3.2^{a}$ & $7128.55 \pm 2.2^{b}$ & $<0.001$ \\
\hline Feed conversion ratio & $1.93 \pm 0.08$ & $1.96 \pm 0.08$ & $1.97 \pm 0.03$ & 0.945 \\
\hline Cannibalism & $3.00 \pm 0.40$ & $1.00 \pm 0.00$ & $0.00 \pm 0.00$ & $<0.001$ \\
\hline Mortality & $4.00 \pm 0.40$ & $1.00 \pm 0.00$ & $2.00 \pm 0.40$ & $<0.001$ \\
\hline
\end{tabular}

${ }^{a, b}$ Means within the same row with different superscripts are significantly different $(P<0.05)$

birds having the highest values (22.95, 76.51, and 44.45) while free range birds recorded the least corresponding values (21.52, 71.74, and 40.01). Birds kept in battery cage recorded the highest $(p<0.05)$ values $(114.83$ and 7463.95) of average daily feed intake and total feed intake, while free range birds recorded the least $(p<0.05)$ values (109.67 and 7128.55). Battery cage had the highest (1.93) feed conversion ability, while free range birds displayed the least (1.97) feed conversion ability. Three cases of cannibalism were recorded in battery cage birds while no cannibalism case was recorded in birds on free range management system. Mortality rate was also on the peak in birds kept in battery cage while birds on deep litter system recorded the least case of mortality.

\section{Economy of production of Isa Brown layers on different} management systems

Table 3 revealed the economic analysis of rearing Isa Brown layers on different management systems. The results of cost benefit analysis showed that the daily feed intake, total feed intake, total cost of feed consumed, quantity of egg produced per bird, revenue generated from eggs, production cost, net benefit, cost-benefit ratio, and percentage cost of production were significantly $(p<0.05)$ influenced by management systems. Birds kept in battery cage recorded the highest $(p<0.05)$ values $(114.83 \mathrm{~g}, 7.46 \mathrm{~kg}$, and 970.34$)$ for daily feed intake, total feed intake, and total cost of feed consumed, while those kept on free range recorded the least $(109.67 \mathrm{~g}$,

Table 3 Economy of production of Isa Brown layers on different management systems

\begin{tabular}{|c|c|c|c|c|}
\hline Parameters & Battery cage & Deep litter & Free range & $p$ value \\
\hline Cost/kg feed ( & $130.00 \pm 0.00$ & $130.00 \pm 0.00$ & $130.00 \pm 0.00$ & $<0.01$ \\
\hline Daily feed intake (g) & $114.83 \pm 0.17^{a}$ & $114.00 \pm 0.52^{\mathrm{a}}$ & $109.67 \pm 0.42^{b}$ & $<0.01$ \\
\hline Total feed intake (kg) & $7.46 \pm 0.01^{a}$ & $7.41 \pm 0.03^{\mathrm{a}}$ & $7.13 \pm 0.03^{b}$ & $<0.01$ \\
\hline Total cost of feed consumed ( & $970.34 \pm 1.41^{\mathrm{a}}$ & $963.30 \pm 4.36^{\mathrm{a}}$ & $926.68 \pm 3.56^{b}$ & $<0.01$ \\
\hline Quantity of egg produced/bird & $47.53 \pm 0.37^{b}$ & $48.87 \pm 0.37^{a}$ & $45.93 \pm 0.37^{c}$ & $<0.01$ \\
\hline Crate of eggs produced/bird & $1.58 \pm 0.01^{b}$ & $1.63 \pm 0.01^{\mathrm{a}}$ & $1.53 \pm 0.01^{c}$ & $<0.01$ \\
\hline Cost of egg/crate ( & $850.00 \pm 0.00$ & $850.00 \pm 0.00$ & $850.00 \pm 0.00$ & $<0.01$ \\
\hline Cost of layers ( & $900.00 \pm 0.00$ & $900.00 \pm 0.00$ & $900.00 \pm 0.00$ & $<0.01$ \\
\hline Operational cost ( $\mathbb{N}$ ) & $104.20 \pm 0.00$ & $104.20 \pm 0.00$ & $104.20 \pm 0.00$ & $<0.01$ \\
\hline Cost of construction( $\mathbb{N})$ & $277.00 \pm 0.37^{a}$ & $222.00 \pm 0.37^{b}$ & $144.00 \pm 0.37^{c}$ & $<0.01$ \\
\hline Revenue from eggs ( & $1346.78 \pm 10.35^{b}$ & $1384.56 \pm 10.35^{\mathrm{a}}$ & $1301.44 \pm 10.35^{c}$ & $<0.01$ \\
\hline Production cost (TVC) ( & $2251.54 \pm 1.64^{\mathrm{a}}$ & $2189.5 \pm 4.51^{\mathrm{b}}$ & $2074.88 \pm 3.81^{c}$ & $<0.01$ \\
\hline Sales of spent birds ( & $1100.00 \pm 0.00$ & $1100.00 \pm 0.00$ & $1100.00 \pm 0.00$ & $<0.01$ \\
\hline Net benefit/profitability index (N) & $195.24 \pm 11.54^{\mathrm{b}}$ & $295.06 \pm 12.92^{a}$ & $326.56 \pm 13.3^{a}$ & 0.05 \\
\hline Cost-benefit ratio & $0.14 \pm 0.01^{c}$ & $0.21 \pm 0.01^{\mathrm{b}}$ & $0.25 \pm 0.01^{\mathrm{a}}$ & $<0.01$ \\
\hline
\end{tabular}


$7.13 \mathrm{~kg}$, and 926.68 ) corresponding values. Birds kept on deep litter system recorded the highest (48.87) number of eggs produced while those on free range system had the least (45.93) number. The cost of construction was recorded to be highest in battery cage system while construction of free range facilities was at the minimum. Revenue generated from egg sold was highest ( 1384.56$)$ in deep litter system while free range recorded the least significant $(p<0.05)$ ( 1301.44) value. Total cost of producing table eggs was significantly $(p<0.05)$ highest ( $\$ 2251.54)$ in battery cage, while free range had the least ( 2074.88 ) cost of production. Free range birds recorded the highest ( 326.56$)$ net benefit, while the least (195.24) benefit was obtained in battery cage. Cost-benefit ratio was significantly $(p<0.05)$ highest $(0.25)$ in free range system while the least value $(0.14)$ was obtained from battery cage system.

$\mathrm{a}, \mathrm{b}, \mathrm{c}=$ means within the same row with different superscripts are significantly different $(P<0.05)$

\section{Discussion}

Weight is also an important factor to consider in the marketability of spent layers. Battery cage and deep litter system have weight gain that are statistically $(p>0.05)$ similar, while the highest weight gain was experienced in birds kept on free range. This could be as a result of the freedom of movement given to free range birds which resulted into feeding distraction or partial concentration on feeding but rather exploring the environment. The results of this study are in agreement with that of $\mathrm{Li}$ et al. (2017) and Wang et al. (2009) who indicated that weight gain in free range and cage free systems was lesser to that of birds kept in conventional cages. Battery cage recorded the highest egg weight, and this is in line with the findings of Voslářová et al. (2006) and DukićStojčić et al. (2009) who reported that markedly heavier eggs were produced by caged layers. Contrary to the reports of Leyendecker et al. (2001), Vlčková et al. (2014), Lewko and Gornowicz (2011), Voslarova et al. (2006), Van-Horne (1996), Muthusamy and Viswanathan (1998), and Petek (1999) who reported that battery cage produced a higher number of eggs and a higher egg mass, deep litter recorded the highest number of eggs per hen per day, higher percentage of hen day production, and egg mass index. Likewise, the results of this study also negate that of Van Den Brand et al. (2004) who reported higher egg production of layers in free range system. In agreement to the reports of Li et al. (2017), birds on free range system had the least daily and total feed intake, while the highest daily and total feed intake was recorded in birds kept in battery cage. Battery cage birds, however, recorded the best feed conversion ratio while free range birds recorded the poorest feed conversion ability which is in agreement with the findings of Ayinde et al. (2012) and Li et al. (2017) who reported that battery cage recorded the higher feed conversion efficiency. Birds may suffer from certain vices (bad habits), which become quite extensive right from the beginning, and their eradication poses a big problem. These vices may incur a huge loss to the poultry farmer. Some of the important poultry vices are cannibalism, egg eating, egg hiding, and pica. Three cases of cannibalism were recorded in battery cage system while free range recorded no case of cannibalism. This might be as a result of cage stress encountered as reported by Fiks-van et al. (2001). Furthermore, it has been acknowledged that conventional cages cause many welfare problems as reported by FAWC (1997). Mortality rate was also higher in birds kept in battery cage system, while those on deep litter recorded the least mortality.

Daily and total feed intake were significantly $(p<0.05)$ influenced by management systems. Battery cage recorded the highest feed intake while birds on free range recorded the least feed intake. This could be as a result of exposing the birds to substrate in which they were able to pick other materials from the soil. Free range birds also have access to forages, insects, and other nutritional matters thereby causing a reduction in feed intake, which in turn reduced the cost of feed incurred. Although the quantity of eggs produced by free range birds was lesser to other management systems, the results of the performance revealed that the hen day production of free range birds falls within the accepted range. Likewise, highest cost of construction was incurred in battery cage system, while free range birds recorded the least cost of construction which in turn might increase its profitability to rural farmers engaged in backyard poultry farming. Highest revenue generated from selling eggs was recorded in deep litter system followed by battery cage system, while free range birds recorded the least generated revenue on egg sales. Total variable cost was highest in battery cage system which was due to high cost of construction, while free range birds recorded the least cost of production. Net benefit and cost-benefit ratio were recorded to be highest in birds kept on free range system. This was as a result of low cost of construction incurred in free range system which resulted into high profit margin. The result of this study is in partial agreement with that of Ayinde et al. (2012) who reported that both battery cage and deep litter system exhibited profitable egg production.

\section{Conclusion}

The performance characteristics (apart from daily and total feed intake) were not significantly $(p>0.05)$ influenced by management systems. Furthermore, economy of production was significantly $(p<0.05)$ influenced by management system. Cost of construction and total cost of production was relatively low, while net benefit and 
cost-benefit ratio were significantly high in free range management system. Based on the results of this study, it was therefore concluded that free range management system resulted into better profit margin and could therefore be adopted by small scale farmers in rural areas willing to practice backyard poultry farming.

\section{Acknowledgements}

The authors hereby acknowledge the management of Daeliza Foods and Agricultural Products Mrs. D. M. Okedere, Miss. Omotuyole Oluwatoyin, and Mr. Oyesomi Damilare for their immense supports and contributions toward the successful completion of this study.

\section{Authors' contributions}

The concept of the study was conceived, designed, and coordinated by ODA. Data collection and data analysis was done by ODA, APQ, and APM. However, writing of the manuscript was done by ODA, and he is responsible for managing all activities of the experiment. All authors read and approved the final manuscript

\section{Funding}

Not Applicable.

\section{Availability of data and materials}

The data supporting the results of this study are available from Okedere Daniel Adeolu. However, restriction applies to the availability of the data, which were used under license for the present study, and are not openly available. Data are, however, available from the author upon realistic request and with the authorization of Okedere Daniel Adeolu.

\section{Ethics approval and consent to participate}

Not applicable.

\section{Consent for publication}

Not applicable

\section{Competing interests}

The authors declare that they have no competing interests.

\section{Author details}

${ }^{1}$ Department of Animal Production and Health, Federal University of Technology, Akure, Nigeria. ${ }^{2}$ Department of Animal Production and Health, Federal University of Technology, Akure, Nigeria. ${ }^{3}$ Department of Agricultural Extension and Communication, Federal University of Technology, Akure, Nigeria.

Received: 27 March 2020 Accepted: 4 May 2020

Published online: 15 May 2020

\section{References}

Afolami C. A., Aladejebi O. J. and Okojie L. O. (2013). Analysis of profitability and constraints in poultry egg farming under battery cage and deep litter systems in Ogun State, Nigeria: a comparative study. IJAFS 4, 2013, 20: 581- 595

Alexander JG (2004) A technology review. Newcastle disease. Food and Agriculture Organization of the United Nations, Rome

Amos TT (2006) Analysis of backyard poultry production in Ondo state, Nigeria. International Journal of Poultry Science 5:247-250

Ayinde, I. A., Ibrahim, S. B. and Arowolo, S. O. (2012). Economics of poultry egg production under two management systems In Ogun State, Nigeria. Nigerian Journal of Agricultural Economics (NJAE) Volume 3(1), 2012. Pages 40 - 49

Belewu, K. Y., Ibrahim, H. K., Ajibade T. B. and Adewusi, O. G. (2018). The cost benefit analysis of incorporating fungus treated Castor seed cake (FTCSC) (Ricinuscommunis) in the diet of (WAD) GOAT. Applied Tropical Agriculture 23 (2), 77-81, 2018

Branckeart, R.D.S., L. Gavira, J. Jallade and R.W. Seiders, (2000). Transfer of technology in poultry production for developing countries. FAO Sustainable Development Dimensions, October 2000 and Proceedings WPC2000 Montreal, Canada.

Burton DL, Cooper EL (2007) Agriscience, fundamentals and application. Thomson Delmar Learning, USA
Damerow G (2002) Barnyard in your backyard. Storey Publishing, Pownal, VT Dukie-Stojeie M, Peric L, Bjedov S, Milosevic N (2009) The quality of table eggs produced in different housing systems. Biotechnology in Animal Husbandry 25:1103-1108

Duncan DB (1955) Multiple range and multiple F tests. Biometrics. 11:1-42. https://doi.org/10.2307/3001478

European Union Council Directive 1999 /74/EC. Retrieved 15 November 2011.

FAWC (Farm Animal Welfare Council). (1997). Report on the welfare of laying hens. Tolworth, England: Author. Fraser, D., Weary, D. M., Pajor, E. A., \& Milligan, B. N. (1997). A scientific conception of animal welfare that reflects ethical concerns. Animal Welfare, 6, 187-205.

Fiks-van Niekerk G.C.M., Reuvekamp B.F.J., Emous R.A (2001) Organic poultry farming: a small but growing concept. In Proceedings of the 6:th European Symposium on Poultry Welfare, Zollikofen, Switzerland, pp. 35-37. Swiss Branch of the WPSA, Zollikofen, Switzerland.

Horne, P.L.M. Van; Achterbosch, T.J. (2008). "Animal welfare in poultry production systems: impact of EU standards on world trade". World's Poultry Science Journal. Cambridge University Press (CUP). 64 (01): 40-52. https://doi.org/10. 1017/s0043933907001705.

Leenstra F, Ten Napel J, Visscher J, Van Sambeek F (2016) "Layer breeding programmes in changing production environments: a historic perspective" (PDF). World's Poultry Science Journal. Cambridge University Press (CUP). 72(01):21-36. https://doi.org/10.1017/s0043933915002743

Lewko L, Gornowicz E (2011) Effect of housing system on egg quality in laying hens. Ann. Anim. Sci. 11(4):607-616

Leyendecker M, Hamann H, Hartung J, Kamphues J, Ring C, Glünder G, Ahlers C, Sander I, Neumann U, Distl O (2001) Analysis of genotype-environment interactions between layer lines and housing systems for performance trails, egg quality and bone strength. 2nd communication: Egg quality traits. Züchtungs-kunde 73:308-323

Meseret S (2016) "A review of poultry welfare in conventional production system" (PDF). Livestock Research for Rural Development. 28(12)

Miao ZH, Glatz PC, Ru YJ (2005) (2005). Free-range poultry production - a review. Asian-Aust. J. Anim. Sci. 18(1):113-132

Muthusamy P, Iswanathan K (1998) Effect of rearing systems on performance of commercial layers. Indian J. Poultry Sci. 33(3):264-267

Nmadu JN, Ogidan IO, Omolehin RA (2014) Profitability and resource use efficiency of poultry egg production in Abuja. Nigeria. Kasetsart J. (Soc. Sci) 35:134-146

Ojo, S.O., (2002). Analysis of the three risk factors in commercial poultry production in Osun State, Nigeria. Proceedings of the 27th Annual Conference of Nigeria Society for Animal Production, March 17-21, 2002, Federal University of Technology, Akure, Nigeria.

Omololu A (1999) Human nutrition in Tropical African. Proceedings of the International Symposium on Animal Production in the Tropics. Heinemann Educational Books Plc, Ibadan, Nigeria

Osei S. A., (2008): The state of animal agriculture in Ghana. Animal Agriculture in West Africa Proceedings of the Joint Silver Anniversary Conference of the Nigeria Society for Animal Production (NSAP) and West African Society for Animal Production (WASAP), Inaugural Conference. Sophie Academic Services Ltd. Abeokuta, Nigeria.

Petek M (1999) Production traits and economic efficiencies of different Genotypes ofa layers reared by enterprises in Bursa province and itTs near vicinity. Veteriner Fakultesi Dergisi Uludag Universitesi. 18(1-2):65-77

Poole TE (2008) Introduction to developing a free-range poultry enterprise. Pp:1-24 https://extension.umd.edu/sites/extension.umd.edu/files/_docs/locations/frederick_ county/Ag\%20Pubs\%20A\%20Supplement\%20to\%20Free\%20Range\%20Poultry.pdf

RSPCA (2005). Cruelty to animals: a human problem proceedings of the 2005 RSPCA Australia Scientific Seminarheld at the Telstra Theatre, Australian War Memorial, Canberra, 22 February 2005 .https://www.rspca.org.au/sites/default/files/ website/The-facts/Science/Scientific-Seminar/2005/SciSem2005-Proceedings.pdf

Weather Spark (2017) Statistical analysis of historical hourly weather reports and model reconstructions from January 1, 1980 to December 31, 2016. https:// weatherspark.com/y/50070/Average-Weather-in-Okuku-Nigeria-Year-Round

SPSS (Statistical Package for Social Sciences) version 15.0, USA. (2006). SPSS 15.0 Comman Syntax Reference. 233, South Wacker Drive, Chicago.

Van den Brand H, Parmentier HK, Kemp B (2004) Effects of housing system (outdoor vs cages) and age of laying hens on egg characteristics. Brit. Poultry Sci. 45:745-752

Van-Horne PLM (1996) Production and economic results of commercial flocks with white layers in aviary systems and battery cages. British Poult Sci. 37(2): 255-261. 
Vlčková, Jana \& Tumová, Eva \& Englmaierová, Michaela. (2014). The effect of housing system on egg quality of Lohmann white and Czech hen. Acta fytotechnica et zootechnica. 17. 44-46. 10.15414/afz.2014.17.02.44-46. Voslářová E, Hanzálek Z, Večerek V, Straková E, Suchý P (2006) Comparison between laying hen performance in the cage system and the deep litter system on a diet free from animal protein. Acta Vet. Brno 75:219-225

Wang KH, Shi SR, Dou TC, Sun HJ (2009) Effect of a free-range raising system on growth performance, carcass yield, and meat quality of slow-growing chicken. Poultry Science 88:2219-2223

Writerstake (2019). Types of poultry rearing systems that will increase your productivity. https://writerstake.com/posts/types-of-poultry-rearing-systemsthat-will-increase-your-productivity Retrieved Wed. Apr 22, 2020

Ying L, Luo C, Wang J, Guo F (2017) Effects of different raising systems on growth performance, carcass, and meat quality of medium-growing chickens. Journal of Applied Animal Research 45(1):326-330

\section{Publisher's Note}

Springer Nature remains neutral with regard to jurisdictional claims in published maps and institutional affiliations.

\section{Submit your manuscript to a SpringerOpen ${ }^{\odot}$ journal and benefit from:}

- Convenient online submission

- Rigorous peer review

- Open access: articles freely available online

- High visibility within the field

- Retaining the copyright to your article

Submit your next manuscript at $\boldsymbol{\wedge}$ springeropen.com 